\title{
Innate and adaptive anti-viral immune responses in MS patients treated with interferon-beta
}

\author{
Thor Petersen ${ }^{1}$, Anné Møller-Larsen², Steffen Thiel², Troels K Hansen³ ${ }^{3}$ Svend Ellermann-Eriksen ${ }^{4}$, Tomasz Brudek²,
} Tove Christensen ${ }^{2 *}$

From 15th International Conference on Human Retroviruses: HTLV and Related Viruses

Leuven and Gembloux, Belgium. 5-8 June 2011

\section{Background}

Interferon-beta (IFN- $\beta$ ) has both immuno-modulating and anti-viral effects. In a longitudinal study of multiple sclerosis (MS) patients undergoing interferon-beta therapy, we have performed a comprehensive study of factors in the innate and adaptive immune response to the two types of virus associated with MS: human endogenous retroviruses (HERVs), and herpesviruses.

\section{Materials and methods}

Anti-viral antibodies towards HERVs and herpesviruses were assayed using TRIFMA or ELISA. Cytokine profiling was performed using the Luminex-system. Factors in the lectin complement activation pathway were assayed using TRIFMA.

\section{Results}

We demonstrate significant decreases in anti-Envelope antibody reactivity for the two closely related Gammaretroviral HERVs, HERV-H and HERV-W, as a consequence of IFN- $\beta$ therapy, closely linked to efficacy of therapy/low disease activity. We also found strong indications of a protective effect of high levels of two components in the innate pathogen-associated molecular pattern recognition: mannan-binding lectin (MBL), and MASP-3.

Serum levels of typical Th1- and Th2- related, MSrelevant cytokines were also monitored. We found no overall changes in Th1/Th2 ratios.

\section{Conclusions}

Our results support that IFN- $\beta$ exerts effects on immune response to HERV-H/HERV-W, and that this

\footnotetext{
* Correspondence: tc@microbiology.au.dk

2Department of Medical Microbiology and Immunology, Aarhus University, Aarhus, DK-8000 C, Denmark

Full list of author information is available at the end of the article
}

antiviral response may play a role in MS development. Components in the immune response to HERVs have potential as biomarkers for disease activity.

\section{Author details}

'Department of Neurology, Aarhus University Hospital, Aarhus, DK-8000 C, Denmark. ${ }^{2}$ Department of Medical Microbiology and Immunology, Aarhus University, Aarhus, DK-8000 C, Denmark. ${ }^{3}$ Department of Endocrinology, Aarhus University Hospital, Aarhus, DK-8000 C, Denmark. ${ }^{4}$ Department of Clinical Microbiology, Aarhus University Hospital, Skejby, DK-8200 N, Denmark.

Published: 6 June 2011

doi:10.1186/1742-4690-8-S1-A214

Cite this article as: Petersen et al:: Innate and adaptive anti-viral immune responses in MS patients treated with interferon-beta. Retrovirology 2011 8(Suppl 1):A214.

Submit your next manuscript to BioMed Central and take full advantage of:

- Convenient online submission

- Thorough peer review

- No space constraints or color figure charges

- Immediate publication on acceptance

- Inclusion in PubMed, CAS, Scopus and Google Scholar

- Research which is freely available for redistribution 